\title{
IQTISHODUNA
}

IQTISHODUNA: Jurnal Ekonomi Islam

E-ISSN: 2443-0056, P-ISSN: 2252-5661

Accredited Sinta 2 Number 148/M/KPT/2020

Volume 9 Issue 2, October 2020 | Page: 197-224

DOI: $\underline{\text { doi.org/10.36835/iqtishoduna.v9i2.490 }}$

\section{Nusantara Syariah Economy (Construction of Economic Cooperation between The Indonesian Muslim Community)}

\author{
AM. M. Hafidz Ma'shum', Marlina² \\ 1,2Masters in Islamic Economics, Institut Agama Islam Negeri Pekalongan, Jl. Kusuma Bangsa \\ No.9 Pekalongan 51141, Indonesia \\ e-mail: ${ }^{1}$ hafidzms@iainpekalongan.ac.id ${ }^{2}$ marlina@iainpekalongan.ac.id
}

\begin{abstract}
This study seeks to answer two problem formulations, namely the construction of economic cooperation practices for the Indonesian Muslim community in agriculture, plantation, livestock, and forestry, and the feasibility of these economic cooperation practices in the Islamic banking industry. The results of this study conclude that the practice of economic cooperation between the Muslim community in the archipelago is constructed through six concepts, namely (1) adat; (2) social capital; (3) oral agreement; (4) profit sharing; (5) 'urf; (6) sharia compliance; and (7) muamalah figh contracts. When viewed from the sociological, juridical, and economic aspects, the practice of economic cooperation in the Indonesian Muslim community is a very potential captive market for Islamic banks. This research strengthens the Granoveterian embeddedness theory which states that economic behavior (in this case is the practice of economic cooperation between the Muslim community in the archipelago) is a social action that is socially structured and positioned. Research at the same time rejects Polanyian's embeddedness, which states that attachment only occurs in pre-industrial societies.
\end{abstract}

Keywords: indonesian sharia economy, granoveterian, economic construction.

\begin{abstract}
Abstrak: Penelitian ini berupaya untuk menjawab dua rumusan masalah, yaitu konstruksi praktik kerja sama ekonomi masyarakat muslim nusantara di bidang pertanian, perkebunan, peternakan dan kehutanan dan kelayakan praktik kerja sama ekonomi tersebut dalam industri perbankan syariah. Hasil penelitian ini menyimpukan bahwa praktik kerja sama ekonomi masyarakat muslim nusantara dikonstruksi melalui enam konsep, yaitu (1) adat; (2) modal sosial; (3) kesepakatan lisan; (4) bagi hasil; (5) 'urf; (6) shariah compliance; dan (7) akad fikih muamalah. Jika dilihat dari aspek sosiologis, yuridis dan ekonomi maka praktik kerja sama ekonomi masyarakat muslim nusantara merupakan ceruk pasar (captive market) yang sangat potensial bagi bank syariah. Riset ini memperkuat teori embeddedness Granoveterian yang menyatakan bahwa perilaku ekonomi (dalam hal ini adalah praktik kerja sama ekonomi masyarakat muslim nusantara) merupakan tindakan sosial yang disusun dan disituasikan secara sosial. Riset sekaligus menolak embeddedness Polanyian yang menyatakan bahwa keterlekatan hanya terjadi pada masyarakat pra-industri.
\end{abstract}

Keywords: ekonomi syariah nusantara, granoveterian, konstruksi ekonomi.

\section{A. Introduction}

This research is motivated by several academic problems as the following description. First, the implementation of Islamic Economics as an economic system has been dominated by the financial and banking sectors. In fact, this sector only represents one piece of mosaic from the many other pieces that form the construction of the Islamic Economic system. Meanwhile, other sectors, especially the real sector, which are basically part of the Islamic Economic system, still do not have much room to be studied so that they can be used as a reference in applying Islamic Economics as a system (Syahbudi, 2013). 
Second, in the midst of the swift flow of the global economy and the octopus of trans-national corporations, it turns out that people's economic practices based on an agrarian economy are still the people's choice. Economic practices such as adol oyodan, nggaduh cows, slethongan, tree rental, nguyang and the like are still the basis of society to fulfill their daily needs. However, economic practices like this have not been institutionalized and in many conditions are not bankable so that they cannot be developed as an investment instrument option (Adawiyah, 2011).

The above conditions are in line with the third academic problem, namely those related to banking products and Islamic financial institutions in Indonesia. One of the problems that has caused the low market share of Islamic banking in Indonesia is the limited types of products offered. In addition to product differentiation, Islamic banks are still constrained by product diversification so that the very varied needs of the community cannot be facilitated by Islamic banks (Hafidz MS, 2015).

Therefore, it needs to be studied and explored, how the concepts and economic practices of Indonesian Muslims are close to the agrarian economy so that an Islamic Economic system will be constructed and presented with an Indonesian character, character and insight, or what is called the Islamic Economy of the Archipelago. The space for exploration and study of local wisdom becomes a separate requirement for the development of a syari'ah economic approach and methodology as well as for the exploration of the nation's cultural treasures in general. Because there are still many opportunities to explore and develop discourse on local wisdom of the archipelago community and make it a model approach in sharia economic studies in addition to the enthusiasm to find the right formulation for shari'ah economic development which provides a unique framework for finding the characteristics of economic practice in Indonesia. so that Indonesian Islam can have a creative and productive dialogue with the economic system of society (Hermansyah, 2013). By using various methodologies such as maqashid syari'ah, al-muhafadzah and al-'adah muhak Court, an economic system that lived and was born from the Muslim community of the archipelago was still in accordance with and fulfilled the principles of sharia (sharia compliance).

Referring to the background problems described earlier, this study seeks to answer two problem formulations, namely (1) the concept and practice of economic cooperation between the Muslim community in the archipelago in agriculture, plantation, animal husbandry and forestry; and, (2) the feasibility of this economic cooperation practice in the Islamic banking industry?

\section{B. Research Methods}

This research is a library research with a qualitative approach. The data used are 
AM. M. Hafidz Ma'shum, Marlina: Nusantara Syariah Economy(Construction of Economic Cooperation between the Indonesian Muslim Community)

secondary data from various studies that have been conducted by previous researchers related to the practice of economic cooperation in the Indonesian Muslim community.

The data used in this study is secondary data from various research related to various types of economic cooperation practices in Muslim communities in Indonesia. The data used are 31 (thirty one) research results in various forms of reports which geographically include Sumatra, Java, Kalimantan, Sulawesi, Nusa Tenggara and Bali.

The data collection technique for secondary data sources is the documentation technique. Internal data validity is done by increasing diligence in collecting, selecting and processing data. Meanwhile, external validity or extrapolation is carried out using the transferability pattern.

The method used to analyze it is content analysis, because this research is a document analysis (document analysis). The steps taken are through data reduction, display data and conclusion drawing. The analysis used is inductive by using a domain analysis which begins by determining the included term, semantic relation and the cover term. The data that has been collected is used as material and a basis for understanding to form a conclusion. The analysis was carried out in a cyclical manner, which means it was carried out from the beginning of data collection to the formulation of the final conclusions.

\section{Research Results}

\section{Concepts and Practices of Economic Cooperation between the Indonesian Muslim Community}

Referring to the tracking of various literatures on the results of research on the practice of economic cooperation of Muslim communities in Indonesia in the fields of agriculture, plantation, livestock and fisheries / ponds, several key concepts are inherent in the various types of economic cooperation practices. Important concepts that are key words are adat, 'urf, social capital, profit sharing, shariah compliance, oral tradition and the muamalah fiqh contract.

\section{a. Tradition}

One of the key words that have high intensity and are emerging in terms of community economic cooperation is "adat." This is because generally the practice of economic cooperation in the Muslim community in the archipelago is a habit that has long been practiced by the community. Therefore, one of the reasons they put forward is carrying out economic cooperation because it refers to the customs that have taken place before. As research conducted by Hermawan (2012) which states that one of the factors influencing the implementation of the agreement for agricultural land products in Waung Village, Baron District, Nganjuk Regency, is the community factor. The point is that the people in the research village have had enough if they follow the customs regarding the sharing agreement that they have been doing. The community still uses customary law as a reference 
for implementing production sharing agreements for agricultural land. People consider customs and culture as part of life. The same applies to the practice of economic cooperation in agriculture in the Birem Bayeun area, Aceh. In this collaborative practice, trust and mutual assistance are the basis for continuing the implementation of the agreement as was done by its predecessors (former people) according to local customs (Rafly, 2016).

The practice of economic cooperation in the Indonesian Muslim community which is based on customs is not only on the aspects of agriculture or cultivation of rice fields, but also on economic cooperation in the field of animal husbandry, as shown in research in Purworejo, Semarang (Yunianto, 2015), and Yogyakarta (Anggraeni, 2016). From these data it can be stated that the practice of economic cooperation in the Indonesian Muslim community is not something that has just emerged. This practice is an institutionalized tradition and has become a habit from previous generations. It can be said that the practice of economic cooperation in the Indonesian Muslim community is not a newly formed form of cooperation, such as buying and selling online or cash on delivery (COD).

In addition, the institutionalized customs and social institutions are generally always maintained and defended by the community. The implication is that if there are members of the community who behave deviantly or are distorted towards the "social agreement", they will receive social sanctions from the community. Therefore, it is not surprising that the behavior of the Muslim community in the archipelago refers to pre-formed customs in order to maintain social cohesion and not be alienated by other members of the community. The existence of adat which refers to the legacy of the previous generation is indeed a necessity that cannot be avoided. the local community (local community) answers the challenges of this life with the wisdom and wisdom they have. The wisdom or wisdom (wisdom) may appear because the experience that has happened so far has made it an answer and a solution to the problems he is facing. The factor of the involvement of the predecessors, the ancestors, who passed on this tradition to the next generation is very important for the maintenance of this wisdom (Hakim, 2014).

b. 'Urf

'Urf as a method of legal istinbath in jurisprudence or Islamic law, is most often mentioned and associated with the practice of economic cooperation in the Muslim community of the archipelago, when compared to other "derivative" methods such as istihsan, istislah or even maslahah mursalah. The practice of 
economic cooperation for the Muslim community of the archipelago which is positioned as a form of sharia economic practice, among others, is the management of customary land land in Kanor District, Bojonegoro Regency. Like Primada and Zaki's study, the practice of cooperation is a form of custom or 'urf that does not contradict the Koran and Hadith. In addition, the practice of cooperation is also based on the principle of mutual acceptance and mutual benefit so as to avoid harm (Zaki, 2015).

The same thing can also be found from economic cooperation in the plantation sector, namely the practice of tapping coconut trees in Sidamulih District, Ciamis Regency. In its implementation, the practice of cooperating in leasing trees in various aspects can be justified according to 'urf. In terms of the subject of the transaction, the object, price, lease period or duration of time and other aspects can provide benefits to all transacting parties so as to create benefits for all parties conducting transactions (Kantika, 2013).

From some of the studies above, it can be stated that the practice of economic cooperation between the Muslim community in the archipelago which has been and is still ongoing today can be categorized as a custom or custom which is categorized as' urf. The implication is that the practice of economic cooperation for the Muslim community in the archipelago can be included as part of the treasury of Nusantara Sharia Economics (Eksan). This means that the practice of economic cooperation in the Indonesian Muslim community, both before the arrival of Islam and after, as long as it does not contradict Islamic law and is socially institutionalized is part of the form of Islamic Economics.

'Urf sahih (as opposed to' urf fasid or contrary to Islamic law) which is socially institutionalized will in the process become living laws or laws that are lived and implemented by the community. As living laws, the practice of economic cooperation for the Muslim community in the archipelago as part of the Exan can be used as a precedent and even jurispredence that is used as a basis for implementing similar economic cooperation practices. In other words, Eksan as another form of Nusantara fiqh which is mixed with 'urf is something that its existence cannot be denied. 'Urf is the main consideration in determining archipelago fiqh, namely' authentic urf which is affirmed in Islam and has an equal position with passages in Islamic law (Harisudin, 2016). 'Urf as a local wisdom, or local genius in the discipline of anthropology, is a combination of God's word and community practice. Conceptually, local wisdom and local excellence are human wisdom that rests on a traditional institutionalized 
philosophy of values, ethics, ways and behavior.

\section{c. Social Capital}

One of the social capital in the practice of economic cooperation in the Muslim community in the archipelago can be seen in the practice of mawah in Aceh as the results of research by Ibrahim (2012). In practice, mawah transactions occur beginning with an emotional relationship between the owner of the capital and the manager. This relationship generally avoids fraud, embezzlement and other immoral acts. In addition, openness and clarity at the beginning made the concept of mawah far from the elements of usury, gharar, and tadlis and there was an element of mutual willingness in its implementation. Likewise, the practice of economic cooperation between the Indonesian Muslim community in Sidenreng Rappang Regency also makes social capital in the form of an element of trust as one of the factors that determines and forms cooperation between landowners and smallholders (Wahyuni, 2013). Cooperation in the field of cattle farming with the rowdy system in the Simalungun area, North Sumatra is also based on the element of trust. Cow owners and breeders or raiders prioritize trust rather than making agreements openly because it will reduce trust between the two (Sudarwati, 2015). Likewise with the practice of gaduh sapi cooperation in the Bali area, where the practice of cooperation is not only driven by economic motives but also influenced by social values called karmaphala. The institutional system of the gaduhan cattle developed because of a combination of economic needs and social value arrangements 1994).

(Simatupang,

Social capital is also an important element in the practice of economic cooperation for the Muslim community of the archipelago in the north coast (pantura) of Central Java, for example in Batang, Pekalongan and Brebes. One example is the adol oyodan system as practiced by the people of Batang, Central Java. The implementation of adol oyodan economic cooperation without involving witnesses, proof of payment, transaction documents and the like because this cooperation is more dominated by the presence of an element of trust among the people who implement the adol oyodan system (Nursiyamsih, 2015). The same thing happened in neighboring Batang, namely in Pekalongan (Wahyuningsih, 2011), Brebes (Iko, 2008) and Indramayu (Sukardi, 2017).

Referring to the above, it appears that the element of trust as one of the important elements in social capital occupies a very vital position in the implementation of economic cooperation practices for the Muslim community in the archipelago. The parties are driven by an element of trust, 
where one party trusts each other, even that trust is stronger than a document, receipt, letter of agreement or other forms of documentary evidence. Land owners fully give up their management rights over land to others without any black and white agreements. Furthermore, the net profit margin received by landowners is not the result of an elaborate profit and loss statement, but simply a sense of trust in the cultivator or cultivator. If there is no element of trust, then this cooperation practice is very difficult to develop in the community.

Social capital itself is only formed if there are a set of values and norms that become a reference in behaving and acting by all members of society. The value of honesty, trustworthiness, being transparent and the like is a derivation of values and norms. If these values are still upheld, social capital will have been formed.

The existence of social capital in the practice of economic cooperation in the Muslim community in the archipelago, where the practice is largely a custom that has existed for a long time - and in the Islamic context some is seen as' urf - on the one hand it seems to refute the embeddedness theory of the school. Polanyian as introduced by Karl Polanyi. According to Polanyi, only in pre-industrial societies, economic activity (in this case the economic cooperation of the archipelago community in various economic sectors) stands as merely economic action, but is also attached to non-economic variables, namely social values one of them is mutual trust or trust. This theory is refuted by the attachment of people's economic actions to non-economic variables such as social values as illustrated by the practice of economic cooperation in the Muslim community of the archipelago.

\section{Profit Sharing}

The profit and loss sharing system as a model of economic cooperation is widely practiced by the Muslim community in the archipelago, although in various variants from one region to another. In Gorontalo District, for example, the owner of a rice field leaves the cultivation of the land to the tenant farmers. Whatever the results of cultivating the land, both profits and losses will be shared (Darwis, 2016). The Muslim community in Bojonegoro has practiced the same thing under the names maron and nelon. The profit sharing system is also practiced by the Muslim community in Sidenreng Rappang, South Sulawesi.

Cooperation based on profit sharing is carried out in the agricultural sector, in which land owners entrust the cultivation of their land to smallholders. If you get a profit, it will be divided according to the agreement, but if you suffer a loss, the land owner will bear the loss (Wahyuni, 2013). Profit sharing is also 
practiced by people on the island of Java, to be precise in Brebes, Central Java (Iko, 2008). The system for implementing the agricultural production sharing agreement in Bulakamba District, Brebes Regency is by implementing the production sharing agreement based on local customary law. In addition, this agreement is based on an agreement between the land owner and the cultivator verbally based on the belief in dividing the proportion of agricultural produce by way of "maro" or "paron" from the total amount of the harvest after deducting costs.

Based on these data it can be stated that the profit-sharing system is indeed commonly practiced by the Muslim community of the archipelago, although with various variations. This variant is formed due to various factors, but the common thread is due to supply-demand problems. When the bargaining of land owners is high, the demand is also high so that the share received by the land owner will be even higher. For example, the element of land fertility. The level of soil fertility is reflected by the type of irrigation and soil type. The better the irrigation system and soil type, the greater the portion that land owners receive; but vice versa. Another element is the availability (supply) of labor. If the labor supply is very high, it will reduce the "price" so that the portion received by the laborer will be smaller. Other factors that contribute to the formation of profit sharing variants are the geographic location of land from other economic sources, the level of land availability and the relationship between land markets and labor (Saptana, 2005). Differences can also be caused by the understanding and traditions that take place in each society. For example, the Bugis and Makassar ethnic groups both use the term Teseng or Tesang to denote a profit-sharing system for animal husbandry cooperation. However, despite using the same name, it turns out that in practice Teseng or Tesang is practiced differently by the Bugis and Makassar ethnic groups (Sirajuddin, 2016). 
AM. M. Hafidz Ma'shum, Marlina: Nusantara Syariah Economy(Construction of Economic Cooperation between the Indonesian Muslim Community)

\section{Shariah Compliance}

Referring to the results of the tracking of a series of data sources in this study, there are three categories of economic cooperation practices for the Indonesian Muslim community when linked to the principles of sharia compliance. The first category is the practice of economic cooperation between the Muslim community in the archipelago which is against the principles of sharia; the second category is economic practices which are partly in accordance with sharia principles but there are some parts that are not yet suitable, and; the third is the practice of economic cooperation between the Muslim community in the archipelago which is completely in accordance with or does not contradict sharia principles.

The first category is the practice of economic cooperation in the Indonesian Muslim community that is against the principles of sharia, which includes the gala system in Aceh and tebasan or ijon in several areas on the island of Java. In the gala system, the murtahin uses the pledge for economic purposes without reducing the amount of the loan given to the pawner or rahin. This kind of practice is not justified by the majority of fiqh scholars. As for the slash or bondage, it is the sale and purchase of plant products that are still in the tree (not yet harvested) so there is a very big chance of garar or uncertainty, whether related to the quality of the goods or even the quantity. The word ijon itself when translated into Indonesian means "green" which means that the object of sale is a plant fruit that is still green and not yet ripe so that its quality when it enters the harvest period is not known. Although there are several types and models of slashes that are carried out in the community, some of these models still leave an element of garar. Another example is plantation cooperation between land owners / coconut farmers and capital owners in Indragiri Hilir. In this case, the owner of capital lends capital to farmers to work on their coconut plantations, but the owner of the capital requires the plantation owner to sell his coconut to the owner of the capital at a certain price set by the owner of the capital (Sabariah, 2014).

With regard to several examples of economic cooperation practices of the Indonesian Muslim community which are included in this first category, they cannot be included as part of Eksan. So in this position it becomes urgent to "socialize the economy of the community" and at the same time "socialize the sharia economy" so that economic cooperation in the practice of economic cooperation in the Muslim community of the archipelago can be adapted to the principles of sharia.

Meanwhile, the practice of economic cooperation in the Indonesian Muslim community which falls into the second 
category is economic cooperation, some of which are in accordance with sharia principles. Included in this category are plantation cooperation between land owners / coconut farmers and capital owners. In this case, the durian tree rental system in Jangkrikan Wonosobo (Mukaromah, 2011), where the durian garden owner rents out durian trees to tenants for a certain period of time. During the lease period, the benefits arising from the tree in the form of durian fruit become the property of the tenant. Although from the aspect of the contract subject and several other pillars of the contract are in accordance with sharia compliance, the object of the contract in the form of the benefits of the durian tree in the form of fruit is something that is not measurable or still leaves an element of salt / uncertainty. In this condition, the object of the contract becomes unclear so that the practice of this cooperation is not fully in accordance with sharia principles. More or less the same is the practice of renting mango trees in the Indramayu area (Shobani, 2016), where the object for lease is not clear / gharar even though the terms of the transaction or contract are in accordance with sharia compliance.

Another practice of economic cooperation in the Indonesian Muslim community that is not fully compliant with sharia is the maro model in Tenggulun Lamongan, East Java.
Basically, this cooperation can be confirmed by the mukhabarah agreement in muamalah fiqh. However, there are at least two things that make this cooperation not fully compliant with sharia, namely those related to the duration of the cooperation that was not stated at the beginning of the transaction and the second is the percentage of profit sharing that was not defined when the transaction was agreed (Hamidah, 2014) . The same thing also happened in Sleman Yogyakarta in terms of the implementation of the agreement for rice field farming (Priyadi, 2015). On the aspects of the subject of the agreement, the object, form, tax payment and profit sharing amount have met the sharia principles. However, in the aspect of the duration of the agreement and the person at risk, it is not yet fully in accordance with what is outlined in general in muamalah fiqh. In this case, the term of the agreement is not explained at the beginning of the contract, so the end of the cooperation is not clear. In addition, if there is crop failure, the rice cultivators will bear all the losses. Another cooperative practice that is similar to this is the Nyeblok tradition in Bekasi, West Java (Al Ashari, 2016)

\section{Oral Tradition}

What is meant by oral tradition is that the practice of economic cooperation for the Muslim community in the archipelago only begins with an oral agreement, without being 
accompanied by an agreement document and also without being strengthened by witnesses. This oral tradition is basically a habit that cannot stand alone, which means that the oral tradition is one of the logical consequences of the role of social capital in the practice of economic cooperation in the Muslim community of the archipelago. Without social capital, there will be no trust. If the trust disappears, then people will not trust other parties, especially those related to economic and ownership issues. If the community loses trust, there will be no economic cooperation based solely on "chatter" without any binding legal documents.

Almost all economic cooperation practices of the Indonesian Muslim community obtained in the study only use verbal or verbal agreements that are not bound or strengthened by a written agreement (Dhania, 2018). There are several notes that can be compiled regarding the tradition of using oral agreements to form an economic cooperation engagement. First, it shows that the element of mutual trust between the parties that are cooperating is very intense. This can be formed if there is a network of interpersonal relationships between them so that the parties are basically "connected" to each other before the contract is agreed. Even in several types of economic cooperation practices in the Indonesian Muslim community, the owners of capital (land, ponds, gardens and livestock) often have more motives to help each other members of the community who economically still need assistance and jobs. Or in other words, that the practice of economic cooperation in the Indonesian Muslim community was also formed because of the factor of wanting to help others so that there is a possibility that investors will behave "nothing to loose."

As with the practice of economic cooperation between the Indonesian Muslim community in Baranti Subdistrict, Sidenreng Rappang Regency, the relationship between land owners and smallholders is included in the ihsan category as a form of nothing to loose. In this case, if the rice fields that are cultivated

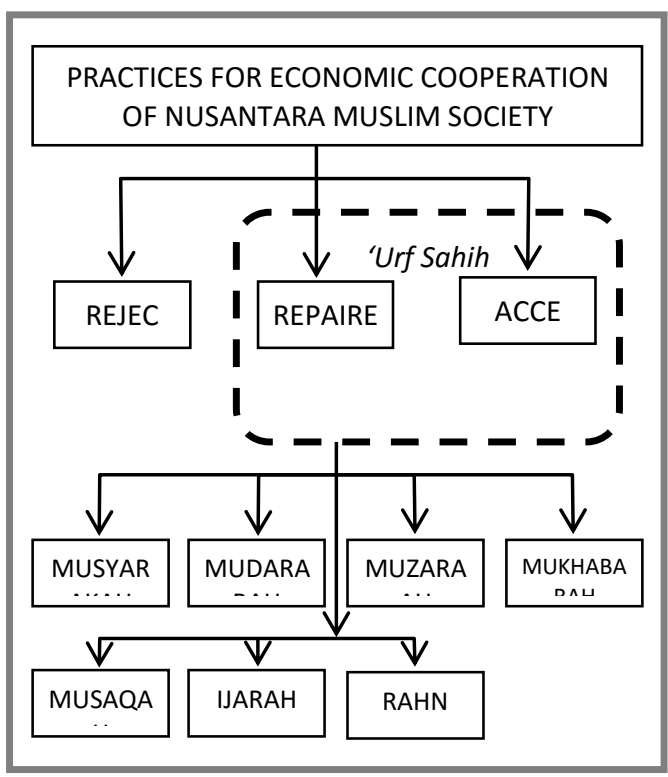

Figure 1

Eksan, shariah compliance, 'urf and fikih

by smallholders experience crop failure or experience problems, the land owner will voluntarily 
give all the cultivated produce to the tenants (Wahyuni, 2013). This kind of practice basically "deviates" from the profit-sharing system of both mudarabah and musyarakah. In mudarabah transactions, the main factors that cause crop failure should first be identified. If it is caused more by smallholders, then the risk should be borne by the cultivator, but if it is caused by a force majeure, the land owner bears the risk. In a musyarakah transaction that uses a profit-loss sharing system, if there is a loss, it should also be shared between the land owner and the cultivator according to their respective capital participation. However, as previously mentioned, the relationship between landowners and smallholders has fallen into the ihsan category, where the motive is to do good to other parties more dominant than the motive for receiving benefits.

Second, that an agreement formed from a verbal or oral agreement is still considered valid, legal and has legal force. Every party who makes an agreement has the freedom to make an agreement, in the sense of being free to make an agreement orally or in writing (Harefa, 2016). Therefore, a person can be declared to have committed an act of default based on the validity of the agreement. However, other supporting evidence is needed to be able to prove that someone has committed an act of default if the person concerned denies the agreement has occurred.

The choice of oral agreement in the practice of economic cooperation for the Muslim community in the archipelago is not only because of the element of trust but also due to other factors. These factors, among others, are due to the ease and simplicity of agreements using verbal agreements (Rohmatin, 2008). The public is more likely to choose this method rather than using agreement documents that seem complicated, complicated, formal and procedural. In addition, this verbal transaction was chosen because it did not reduce the essence and substance of the contract so that the contract was still considered valid and binding (Kantika, 2013). Another factor is that because mutual trust in the community has been built, there will be a feeling of discomfort if the agreement must be stated in a written document, which can be interpreted as implicitly there is an element of distrust from one party to another.

\section{The Fikih Muamalah Agreement} Archipelago Islamic economics is a manifestation of the flexibility of Islamic sharia without being deprived of fundamental principles. It is a link between universal values in shari'a and particularity, where universal values co-exist with and guide the elements contained in particularity to conform to the purpose of being revealed by sharia (maqashid 
asy-syariah). Therefore, it becomes very urgent to identify how the fit between the economic cooperation practices of the Indonesian Muslim community and the types of contracts contained in muamalah fiqh. This suitability is of course not just mirroring, but provides room for accommodating particularities that do not violate the universal values of the Shari'a.

Based on the data that has been collected, it can be stated that the practice of economic cooperation between the Muslim community in the archipelago which is not against shraiah compliance, either in whole or in part, can be "justified" by using several types of contracts / transactions in muamalah fiqh (see figure 2). There are at least seven transactions in muamalah fiqh that are closely related to the practice of economic cooperation in the Muslim community in the archipelago, namely musyarakah, mudarabah, mukhabarah, muzaraah, musaqah, rahn and ijarah.

a. Musharaka

The practice of economic cooperation between the Muslim community in the archipelago which is included in the category of musyarakah or at least analogous to musharaka includes cooperation in the fisheries sector in
Lamongan, where the Tiger Club fish farmer group collaborates with PT. Sumatra Aquaculture includes mutual capital in fisheries cooperation (Ike Danis Fatussunah, 2016). Musharaka is also used in collaboration between fishermen and boat owners as in a study conducted by Masyhuri which states that the musyarakah system and profit-sharing system as an effort to equalize risks that live among fishermen after going through a sufficient time process have been institutionalized as a fishermen's value system, values that serve as a reference for action. This value system can be said as "risk equalization ethics", namely the institutionalized code of ethics of fishermen as a result of fishermen's adaptation to risky fishing businesses and irregular income patterns (Masyhuri, 2013).

b. Mudarabah

The practice of economic cooperation for the Indonesian Muslim community which is included in the mudarabah category is like the practice of the Aceh mawah. In this pattern of cooperation, land owners as owners of capital and land owners entrust their land and capital to be cultivated by smallholders, with the 
level of profit and loss sharing that they agree on together (Ibrahim, 2012). Cooperation in the field of fisheries / ponds in Ogan Ilir Regency, South Sumatra (Anggraeni, 2017) is also included in the mudarabah category, where the pond owner provides all the capital (land, seeds, feed, electricity and so on) so that he is positioned as sahibul maal while the land cultivator is mudarib.

c. Mukhabarah

The practice of economic cooperation for the Indonesian Muslim community, which can be analogized to Mukhabarah, is the sharing system for lowland farming in Sleman Yogyakarta (Priyadi, 2015). In this cooperative practice, the cultivators provide the tools and materials for production in the form of goods divided in the form of crops such as unhulled rice, rice or money from the sale of the crops. The amount of profit sharing has been determined at the beginning of the transaction using the netprofit sharing system. The practice of mukhabarah is also carried out by the Kute Panang Aceh community which they call due tanoh (Faridah, 2017).
The collaboration carried out by the people of Kute Panang District has a method similar to that of mukhabarah in general, namely the parties work together after the agreement is signed. The manager itself will then have the power over the land entrusted to it to be worked on immediately, with the terms agreed at the beginning of the contract.

d. Musaqah dan Muzaraah

The practice of economic cooperation for the Muslim community of the archipelago which can be practiced with the musaqah agreement is the practice of sharing Aren in Mandailing Natal, North Sumatra (Saparudin, 2011). There are indeed five variants of the cooperation model in the area, namely the rental system, the system for two, the system for three, the trunk system and the helping system, however, of the various types of contracts contained in muamalah fiqh, the closest is the musaqah contract. and muzaraah. Musaqah agreements can also be found in the practice of economic cooperation for the Muslim community in the archipelago in Way Kanan Regency, Lampung (Ariyanto, 2017). The 
community works together in terms of cultivating rubber gardens, where the owner of the plantation entrusts the cultivation of his rubber plantation to smallholders to be processed in order to generate profits that will be shared between the two parties. As for the amount of profit sharing, generally using the half-way system.

Meanwhile muzaraah can be found in Birem Bayeun Kab. East Aceh (Rafly, 2016), Kubu Raya West Kalimantan (Rasiam, 2016) and Muncar Banyuwangi East Java (Nisa, 2017). At Birem Bayeun, tenants work on other people's land through production sharing agreements, based on a verbal agreement between the land owner and the tenants based on trust. The distribution of agricultural products is also carried out in accordance with the agreement of both parties. Usually the land owner offers to cultivate his land to his neighbors who are previously known to the land owner, because usually the implementation of the production sharing agreement is based on trust and the basis of an agreement between the two parties. Meanwhile in
Bojonegoro, the harvest will be divided in half between the land owner and the tenants with a composition of $80 \%$ for land owners and $20 \%$ for smallholders.

e. Rahn

Rahn practice can be found in the community of Luo Polewali Mandar District, West Sulawesi (Alwi, 2016). In that area, there are three forms of cooperation in rice field pawnshops, namely ta'gal ruttu, ta'gal naumboyang and ta'gal sibare. Among the three models, ta'gal ruttu is the one that is

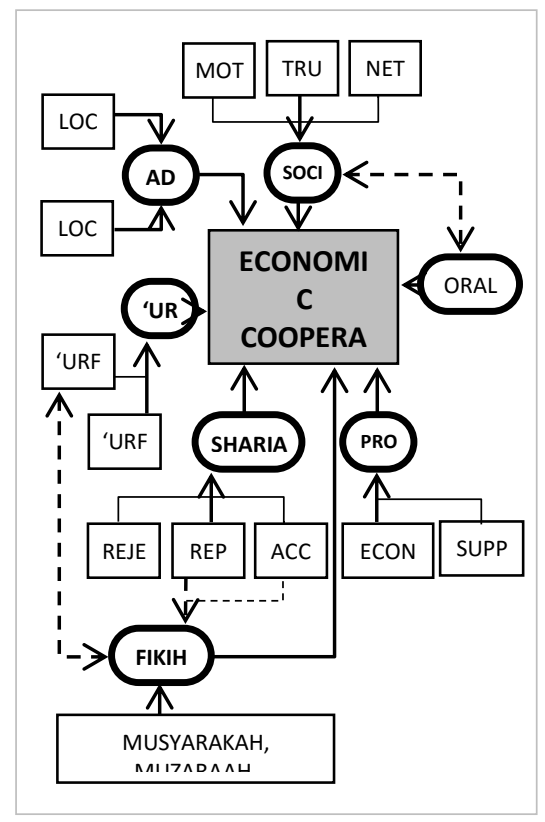

Figure 2

The elements in the

numation of nomunmin

relevant to the pawning / rahn contract in Islam because between rahin and murtahin no one is harmed 
by the same benefits, Rahin is not burdened with paying his debt because the rice fields (marhun bih) are pawned. made into payment of debts to murtahin so that he gets certainty in the payment of his debt.

Rahn contract practices can also be found in the practice of economic cooperation between the Muslim community in the archipelago in Mamasa Regency, West Sulawesi, namely in the form of pawning paddy fields or agriculture. There are two types of pawning in Mamasa Regency, namely regular ta'ga 'and ta'ga dipa'dua (Muchsin, 2016). In the first type of pawning, the land that is pawned is then processed and cultivated by the pawnshop recipient as well as enjoying the results of cultivating the paddy field. Whereas in the second type of pawn or ta'ga 'dipa'dua, the rice fields are cultivated by the pawner or the land owner, but the harvest is partially divided by the recipient of the pawn. This second type of pawn is more similar to the rahn contract in muamalah fiqh.

Another form of pawning is land pawning as practiced by Muslim communities in the Bogor area (Jajuli, 2015) and in the
Minangkabau area, the practice of pawning is called pagang pawn (Hasnaeni, 2015). However, based on a review of Islamic land pawning law, the practice of land pawning in the Bogor Regency community is included in the category of fasid contracts. It is said that the fasid contract is because in its implementation it contains elements of usury which are prohibited by religion, namely taking more profit from the goods lent. So in this case the pawning recipient (murtahin) uses the pawning land for his own economic interests.

The relationship between the seven elements as above and the practice of economic cooperation in the Indonesian Muslim community can be visualized in Figure 2.

\section{Exan Eligibility in the National Sharia Banking Industry \\ a. Sociological}

A product, whether in the form of goods or services, will not be absorbed in the market if it does not consider the social or sociological aspects of the market. Target market relations and interactions are very important to be used as one of the parameters for compiling a product, because if this element is neglected, the acceptability will be very low. Trading beef meatballs is not a business that is prohibited by law and is not an illegal act. However, beef meatball products do not have good business prospects if 
they are marketed in Bali and Kudus, because the two regions still view that cows are animals that are classified as "sacred" so they are not suitable for consumption because of this belief.

The Indonesian Muslim community represents one of the target markets for the Islamic banking industry in Indonesia, and is sociologically very relevant and compatible with the sharia banking business flow using two indicators, namely social capital and the profit sharing system.

\section{i. Social Capital}

As the data described in the previous section, social capital which includes trust, network and social motive occupies a very urgent position in the practice of economic cooperation in the Indonesian Muslim community. This cooperation can be formed and carried out because of the existence of networks, be it kinship networks, neighbors or others which then give rise to social motives for interaction, even in economic interactions. The network that was formed which then gave rise to social motives was based on the element of trust which became the most fundamental basic capital.

Social capital, which is an important component in the practice of economic cooperation in the Indonesian Muslim community, can be an important capital in an effort to involve Islamic banks in the practice of economic cooperation. The prudential principle applied by
Islamic banks with a denser intensity than conventional banks will be easier to implement in its various products if trust and networking have been built between the community as customers and the Islamic bank. The existence of social capital is also a necessity for Islamic banks that apply the principle of "know your customer" because of the formation of networks because the parties involved in it already know and recognize each other.

On the other hand, social capital is also very much needed in one of the principles in financing distribution, namely character. Islamic banks will not possibly cooperate with parties whose character is unknown because it has an impact on the possibility of risk. In general, in addition to studying

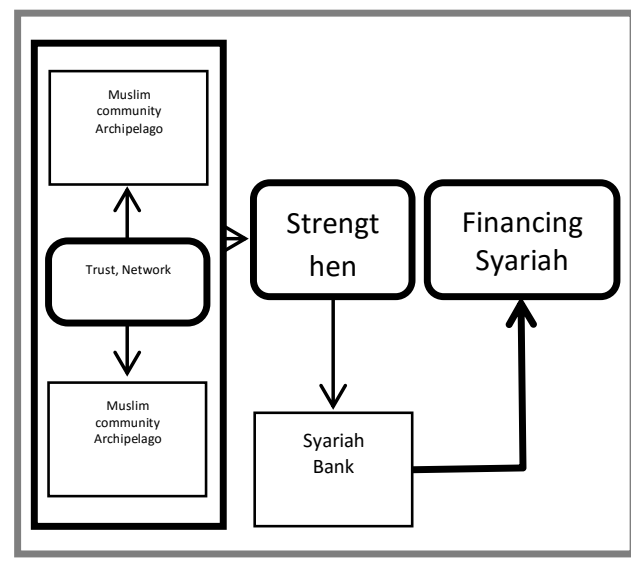

Figure 3

Social Capital to increase

cooperation / financing proposals, the bank will conduct interviews and surveys to determine the eligibility of potential customers. This is to find out customers who want to apply for cooperation / financing, regarding the background, life habits, customer lifestyle, and others. The essence of 
this character principle is to assess whether a prospective customer can be trusted in cooperating with a bank. This step can certainly be bridged if the social capital owned by the prospective customer has been formed as illustrated in Figure 3.

In addition, the existence of social capital can also minimize the potential for moral hazard by customers. Moral hazard is a form of risk for Islamic banks that is included in the unacceptable category, or a risk that Islamic banks cannot accept (Tsabita, 2014). If there is moral hazard, it will result in default, so that it can increase the Non-Performance Finance (NPF) figure, even though the NPF in the agricultural sector is one of the variables that greatly affects the size of Islamic bank financing for agriculture (Mughits, 2016).

\section{ii. Profit Sharing}

The practice of economic cooperation in the Muslim community of the archipelago as described in the previous section is more dominated by the profit sharing system, although with very various variants. This system certainly has a very strong relevance to Islamic bank products which "basically" tend to be profit-sharing banks, even the legality of the operation of Bank Muamalat as the first Islamic bank in Indonesia because of the mandate of the law which uses the term "profit sharing bank."
Referring to this, the opportunity for Islamic banks to enter into the practice of economic cooperation in the Indonesian Muslim community is very wide open. In addition, by entering into the practice of economic cooperation in the Indonesian Muslim community, Islamic banks will have the opportunity to further enlarge the portion of the contract scheme based on profit sharing such as musyarakah, mudarabah, muzaraah and the like because so far, fixed return schemes such as murabahah are very dominant in financing products to its customers. With the muzaraah scheme, for example, the advantages of productionsharing-based agricultural financing such as muzaraah are more familiar with the habits of people in various regions in Indonesia who generally have cooperated with traditional production sharing (Nugraha, 2016).

For products that use a musyarakah contract, Islamic banks can be positioned as parties that include capital, either in the form of money, machinery, or the like as needed. As for mukhabarah or muzaraah, Islamic banks can take the position of providing seeds, seeds, fertilizers and or the like. If using the Ijarah Muntahiya BitTamlik agreement (lease terminated with ownership), Islamic banks can provide production equipment such as 
tractors, fish pond fan machines and the like.

The profit-sharing system represents one of the elements of an economic system that puts forward the aspect of justice; emphasizes distribution rather than growth; and togetherness rather than selfinterest. This is one of the many points of contact between the spirit implied by the practice of economic cooperation between the Muslim community in the archipelago and the spirit promoted by Islamic banks. Through the musyarakah and mudarabah contracts that have been used by Islamic banks (even though in a very limited amount of the total financing channeled), Islamic banks will not ensure anything that is uncertain. In this case, Islamic banks do not require a fixed percentage of returns as in the interest system, because the amount of return is relative to the profits derived from funds included in the customer's business / business. This scheme has many similarities with the profit sharing system implemented in the practice of economic cooperation for the Muslim community in the archipelago. On the other hand, this profit-sharing system is seen as more appropriate to the business climate which does have the potential for profit and loss (Arman, 15).

\section{b. Juridical}

\section{i. Written Document}

$\mathrm{T}$ he more complex and dynamic human civilization, including the economic aspect, necessitates a set of evidence to support the existence of a fact or event. Buying and selling, leasing and a series of other economic activities are economic facts. To confirm and ensure that these facts do exist and cannot be denied by other parties who are directly or indirectly related, a series of supporting evidence is required which can be in the form of written documents, witnesses, evidence and so on.

However, from the data obtained, it appears that almost no economic cooperation practices for the Muslim community in the archipelago use written documents as evidence of this cooperation practice. As long as there is an oral agreement from each party, the transaction or agreement is deemed to have occurred. Because there is mutual trust between the parties, they do not need documents that prove the existence of the agreement, because they believe that the other parties who are transacting will not deny the existence of this fact and comply with what has been agreed.

It is in this part that the practice of economic cooperation in the Indonesian Muslim community is not compatible with the "culture" in the Islamic banking industry as one of the entities of modern business that requires written documents. The practice of 
economic cooperation for the Muslim community in the archipelago does not require written documents or other supporting evidence; but on the other hand every transaction carried out by a sharia bank, especially by looking at other parties, must always be recorded so that there are traces that can be traced.

There is indeed a positivistic culture streak related to the need for a written document for a cooperation agreement involving several parties. This culture assumes that something exists or exists if it can be proven, observable and tangible where one of the parameters used is a written document. This is basically in line with one of the commands in the Koran which states to take notes (written documentation) if there is an economic cooperation (in this case is a debt) for a certain period of time.

This order is not in context because one party lacks or does not trust the other party so there must be a written document, but this paragraph is more of an attempt to anticipate if there is negligence or forgetting so that it can then refer to the document. If there is negligence, it can have negative consequences which lead to losses suffered by one or several parties. Therefore the order to make documents (body facts) is more encouraged as an effort to minimize the occurrence of obscurity (garar) caused by negligence due to time problems.

Some of the data obtained from the economic cooperation practices of the Indonesian Muslim community basically presents the findings that the economic cooperation agreement that has occurred is only based on verbal agreement, which still leaves room for uncertainty. The forms of uncertainty include:

1) the duration of the appointment

2) The end of the cooperation agreement period

3) The party who bears the loss if there is a loss

The existence of this uncertainty will certainly be detrimental to certain parties so that economic cooperation which should be mutually beneficial is difficult to materialize.

\section{ii. Collateral}

Collateral or guarantees have become commonplace in economic activity. Guarantee represents the good faith of the party conducting an economic transaction; and on the other hand provides a sense of security (assurance) for the other party. In Indonesia there are also known pawnshops which are basically a metamorphosis of the type of pawning contract. In the muamalah fiqh realm, the rahn contract is also known, which in many ways is similar to the 
practice of pawning in Indonesian society.

Islamic banks in some of the financing products offered to the public also require goods that can be used as collateral, both in the form of securities / documents, valuables and other forms of economic value. In the murabahah vehicle financing contract, for example, the bank will hold the BPKB (Proof of Ownership of Motor Vehicle) of the vehicle that is used as the object of murabahah financing.

From the data that has been collected, it is known that the majority of economic cooperation practices in the Indonesian Muslim community tend not to use collateral for the various types of cooperation they do. Collateral is not needed because the cooperation they do is more dominated by mutual trust so that each party conducting the transaction is not worried if there is a party who defaults. The absence of collateral is also an impact because some actors in the practice of economic cooperation in the Indonesian Muslim community are driven and driven by social motives, so that in certain contexts and conditions they make them nothing to loose.

This is of course a bit contradictory to the demands of the contemporary business world which require collateral. In this context, Islamic banks can compile a financing scheme for the practice of economic cooperation in the Indonesian Muslim community using the fiduciary principle, where objects that are used as collateral can still be utilized by the owner of the goods, in this case, people who receive financing from Islamic banks. In the mudarabah agreement, for example, it is possible for a sharia bank as a sahibul maal or capital owner to require collateral, for example a plot of rice, but the rice field can still be cultivated by farmers who receive Islamic bank financing.

\section{c. The Economy}

\section{i. Real Sector}

As one of the components in the complex economy and modern business, Islamic banks in Indonesia although still on a limited scale due to their small market share - are able to represent themselves as financial institutions capable of leveraging the real sector of the economy. Islamic bank financing products are more dominated by financing products to the real sector, even the majority to the Micro, Small and Medium Enterprises (MSMEs) sector (Sanrego and Rusydiana, 2009). The ability of Islamic banks to move the real sector of the economy is also indicated by the high value of the Financing to Deposit Ratio (FDR); this means that the funds collected from depositing customers are "used up" to finance customers who need 
financing. Although Islamic bank financing products are dominated by products that use a murabahah contract, this does not mean that murabahah products are used for consumptive financing. In many cases, the use of murabahah financing which is used for production purposes is a bypass because of the limitations of Islamic banks to go deeper into the real sector.

Referring to the practice of economic cooperation in the Indonesian Muslim community as shown from some of the data in the previous section, all of these cooperation practices represent the real sector of the economy. The practice of economic cooperation for the Muslim community in the archipelago is able to increase the number of offers in various sub-sectors, both for agricultural products, plantations, fisheries and livestock. The level of supplydemand that is formed from the practice of economic cooperation in the Indonesian Muslim community is truly a reflection of the real sector of the economy.

This condition certainly makes the opportunity for the entry of the national Islamic banking industry in various types of economic cooperation practices for the Muslim community of the archipelago to be wide open. Islamic banks can only channel their financing to the real business / business sector as the type of business / business is carried out in the practice of economic cooperation in the Muslim community of the archipelago. Even if Islamic banks enter the monetary sector, the portion is not that large.

On the other hand, the participation of Islamic banks in financing the real sector, such as the agricultural sub-sector, for example, can minimize the three "negative" traits that have been attached to agricultural financing schemes. One of these characteristics is that there is a gap in the "business space" between borrowers (debtors) and lenders (creditors). The debtor, in this case the farmers, is fully engaged in the real sector, while creditors are only engaged in the monetary sector. Consequently, the risk of business failure in general will only be borne by the debtor, while the creditor will still benefit at the determined interest rate. There is no complete synergy between debtors and creditors because each moves partially in a different calculation system (Ashari and Saptana, 2005).

\section{ii. Profitability} Islamic banks represent an institution that stands on two legs whose functions are complementary. The first function is as a profitoriented business entity through its intermediary function which brings together 
AM. M. Hafidz Ma'shum, Marlina: Nusantara Syariah Economy(Construction of Economic Cooperation between the Indonesian Muslim Community)

surplus people (saving customers) and people who need financing. To be able to carry out this function, Islamic banks must indeed obtain material benefits that are used to finance the first function above. The second function is the capacity of the Islamic bank as a pillar of the Islamic economy that carries out social functions, such as the distribution of benevolent funds such as zakat, infaq, alms and the like.

The combination of these "two legs" implies that the meaning of profit / profit for Islamic banks is not only measured through quantitative indicators and financial indicators. The meaning of "profit" for Islamic banks can be extended beyond the figures shown by ROA, ROE, DPK, OEOI, NPF, FDR, PYD and so on. Islamic banks will obtain and create profits when providing many financing products provided for the practice of economic cooperation for the Indonesian Muslim community. Why can this be concluded? Here are three basic arguments.

First, by providing financing products that are accessible to Muslim communities who carry out economic cooperation practices, at that time Islamic banks are also moving the real sector of the economy. With another expression, it can be stated that Islamic banks also create jobs from the businesses they finance. Islamic banks add to the aggregate supply for certain goods / commodities so that it raises the level of regional or even national productivity. The supply of rice increased, corn increased, soybean increased, fish increased and so on. This is the advantage that Islamic banks create and earn.

The second advantage is the practice of economic cooperation in the Indonesian Muslim community in the fisheries, livestock, plantation and agriculture sectors to produce or produce consumer goods for the community. Production results of this kind have a clear captive market, because they are consumer goods needed by all levels of society from various classes, be it economic, social, educational and so on. What is produced by the economic cooperation practice of the Indonesian Muslim community is goods that are easy to sell because the market is clear, large and the market does require the availability of these goods.

The third advantage, because it produces consumer goods, indirectly Islamic banks can reduce the negative impact of inflation. The point is that when there is inflation, the trend so far is that food / consumption is the main contributor to inflation. This means that foodstuffs will have the greatest impact and will be directly affected if inflation 
occurs. The implication is that individuals have to spend more of their budget for consumption purposes or $C$ in the equation $Y$ $=\mathrm{C}+\mathrm{S}+\mathrm{Sd}$. For people with a low level of $Y$, the income $(Y)$ they get will be more eroded to finance $C$, and of course those who fall into this category are the lower class people. The negative effects of inflation can be minimized or suppressed if the supply of foodstuffs can be increased, as is the result of the economic cooperation practices of the Muslim community in the archipelago.

\section{Finality}

Referring to the discussion described in the previous section, the following points can be concluded:

a. The construction of the practice of economic cooperation in the Muslim community of the archipelago is closely related to several inseparable components, namely: customs, social capital, oral traditions, profit sharing, 'urf, shariah compliance and muamalah fiqh contracts.

b. By referring to the sociological, juridical and economic aspects, the practice of economic cooperation in the Indonesian Muslim community is part of a business that is bankable or feasible to be financed or cooperating with Islamic banks.

Theoretically, this research strengthens the Granoveterian embeddedness theory which states that economic behavior (in this case is the practice of economic cooperation in the Indonesian
Muslim community) is a social action that is socially structured and positioned. Embedded economic behavior with non-economic variables such as togetherness, mutual help and the like. At the same time, this research rejects Polanyian's embeddedness, which states that social cohesion only occurs in pre-industrial societies.

In practical terms, this research recommends the Islamic banking industry in Indonesia to diversify its products, both funding, financing and other services, which can "accommodate" the economic cooperation practices of the Indonesian Muslim community. Apart from the fact that this cooperation practice is indeed very bankable, this step is an effort to expand the captive market so that it has an impact on a larger market share of Islamic banks.

\section{REFERENCES}

Al-Ashari, Abul Hasan. 2016. Penggarapan Sawah Dengan Cara Nyeblok Di Desa Karang Satu Kecamatan Karang Bahagia Kabupaten Bekasi. Thesis not published, UIN Sunan Gunung Djati Bandung.

Alwi, Muhammad, "Praktek Gadai Sawah pada Masyarakat Kecamatan Luyo Polewali Mandar Perspetif Etika Bisnis Islam", J-ALIF: Jurnal Penelitian Hukum Ekonomi Syariah dan Sosial Budaya Islam, Vol. 1, No. 1, Nopember 2016, page 15-27.

Anggraeni, Reni. 2017. Tinjauan Fiqh Muamalah terhadap Pelaksanaan Bagi Hasil Pengelolaan Tambak. Studi Kasus Desa Seribandung 
AM. M. Hafidz Ma'shum, Marlina: Nusantara Syariah Economy(Construction of Economic Cooperation between the Indonesian Muslim Community)

Ogan Ilir", thesis not published, UIN Raden Fatah Palembang, Ariyanto, Sigit. 2017. “Mekanisme Bagi Hasil (Paroan) Penggarapan Kebun Karet antara Penggarap dan Pemilik Kebun dalam Perspektif Hukum Akad Muamalah: Studi Kasus di Desa Tegal Mukti Kab. Way Kanan Lampung", thesis not published, UIN Maulana Malik Ibrahim Malang.

Arman, etc., Penerapan Bank Pertanian Syariah sebagai Upaya Meningkatkan Hasil Pertanian dan Pemerataan Ekonomi di Sulawesi Selatan dalam Menghadapi Asean Economic Community 2015", Jurnal Pena, No. 1, Vol. 2, 2015, page. 180-189.

Ashari dan Saptana, "Prospek Pembiayaan Syariah untuk Sektor Pertanian", Jurnal Forum Penelitian Agro Ekonomi, Vol. 23, No. 2, December 2005, page 132147.

Baso, Ahmad. 2015. Islam Nusantara: Ijtihad Jenius $\mathcal{E}$ Ijma' Ulama Nusantara. Jakarta: Pustaka Afid Creswell, J. W. 1998. Qualitative Inquiry and Research Design. California: Sage Publication.

Danis Fatussunah, Ike. 2016. Kerjasama Budidaya Ikan Kerapu antara Penggarap dengan Pemodal: Tinjauan Hukum Perdata dan Hukum Islam, Studi Kasus di Desa Labuhan Brondong Lamongan. Thesis not published, Fakultas Syariah UIN Maulana Malik Ibrahim Malang.

Darwis, Rizal, Sistem Bagi Hasil Pertanian pada Petani Penggarap di Kabupaten Gorontalo Perspektif Hukum Ekonomi Islam", Jurnal Al-
Mizan, Vol. 12, No. 1, June 2016, page 1-25.

Dhania, Gita Tri. 2018. Pelaksanan Perjanjian Bagi Hasil Pertanian di Desa Lestari Dadi, Kecamatan Pegajahan, Kabupaten Serdang Bedagai. thesis not published, Universitas Sumatera Utara.

Faridah, Syarifah Nurul. 2017. "Implementasi Akad Mukhabarah pada Pengelolaan Perkebunan Kopi di Kalangan Masyarakat Kec. Kute Panang Kab. Aceh Tengah", thesis not published, UIN ar-Raniry Banda Aceh.

Geertz, Clifford. 1973. Religion as Cultural System," dalam The Interpretative of Culture: Selected Essays, ed. Clifford Geertz. New York: Basic Books.

Hafidz MS., AM. M., "Keterlekatan Sosial Inovasi Produk Bank Syariah di Indonesia," Jurnal Hukum Islam, Volume 13, issue 2 (December 2015).

Hakim, Abdul, "Kearifan Lokal dalam Ekonomi Islam: Studi atas Aplikasi al-'Urf sebagai Dasar Adopsi”, Jurnal Akademika, Vol. 8, No. 1, June 2014, page 65-81.

Hamidah, Iin, "Kesesuaian Konsep Islam dalam Praktik Kerja Sama Bagi Hasil Petani Desa Tenggulun Kec. Solokuro Kab. Lamongan", thesis not published, UIN Syarif Hidayatullah Jakarta, 2014.

Harefa, Billy Dicko Stepanus, "Kekuatan Hukum Perjanjian Lisan Apabila Terjadi Wanprestasi", Jurnal Privat Law Vol. 4 No. 2 July - December 2016, page 113-122.

Harisudin, M. Noor, "'Urf sebagai Sumber Hukum Islam (Fiqh) Nusantara," Jurnal Al-Fikr, Vol. 20, Nomor 1, 2016, page 66-86. 
Hasnaeni, "Tradisi Lokal Pagang Gadai Masyarakat Minangkabau dalam Perspektif Hukum Islam", Islam Realitas: Journal of Islamic \& Social Studies, Vol. 1, No.1, June 2015, page 6981.

Hermansyah, "Kearifan Lokal sebagai Model Pendekatan Ekonomi Syariah," Jurnal Istinbath, vol. 12, no. 1 (December 2013).

Hermawan, F. "Pelaksanaan Perjanjian Bagi Hasil Tanah Pertanian: Studi di Desa Waung Kecamatan Baron Kabupaten Nganjuk,"Jurnal Ilmu Hukum Mizan, Vol. 1, No. 2, December 2012, page 91-99.

Ibrahim, Azharsyah, "Praktik Ekonomi Masyarakat Aceh dalam Konteks Ekonomi Islam: Kajian terhadap Sistem Mawah dan Gala", Proceeding of The Aceh Development International Conference 2012, Malaysa: International Islam University Malaysia, Maret 2012, page 443451.

Iko, Hidup, 2008. Pelaksanaan Perjanjian Bagi Hasil Tanah Pertanian di Kecamatan Bulakamba Kabupaten Brebes Jawa Tengah. tesis tidak diterbitkan, Program Pascasarjana Fak Hukum Universitas Diponegoro Semarang.

Iwou, Chux Ghervase, "Impact of Product Development and Innovation on Market Share", African Journal of Business Management, Vol. 4, No. 13, (OCtober 2010).

Jajuli, M. Sulaeman, "Kepastian Hukum Gadai Tanah dalam Hukum Islam di Kabupaten Bogor", Jurnal Ahkam, Vol. 15, No. 2, Juli 2015, page 221-230.
Johnson, Doyle Poule. 1994. Teori Sosiologi Klasik, alih bahasa Robert Z. Lawang. Jakarta: Gramedia Pustaka Utama.

Jurdi, Syarifudin. 2012. Awal Mula Sosiologi Modern: Kerangka Epistemologi, Metodologi, dan Perubahan Sosial Perspektif Ibn Khaldun. Yogyakarta: Kreasi Wana.

Kantika. 2013. Tinjauan Hukum Islam terhadap Praktik Sewa Menyewa Pohon Kelapa Sadap di Desa Cikalong Kec. Sidamulih Kab. Ciamis. thesis not published, UIN Sunan Kalijaga Yogyakarta

Kantika. 2013. Tinjauan Hukum Islam terhadap Praktik Sewa Menyewa Pohon Kelapa Sadap di Desa Cikalong Kecamatan Sidamulih Kabupaten Ciamis" thesis not published, Fakultas Syariah dan Hukum UIN Sunan Kalija Yogyakarta.

Leksono, Sonny. 2013. Penelitian Kualitatif Ilmu Ekonomi: Dari Metodologi ke Metode, Jakarta: Rajawali Press

Luthfi, Khabibi Muhammad, "Islam Nusantara: Relasi Islam dan Budaya Lokal" Jurnal Shahih, vol. 1, no. 1 (2016).

Masyhuri, "Ekonomi Syariah dalam Etika Pemerataan Risiko", Jurnal Ekonomi dan Pembangunan, Vol. 21, No. 2, December 2013, page $125-136$

Muchsin, "Tinjauan Hukum Islam terhadap Praktek Gadai Sawah: Studi Kasus Desa Salu Mamasa", J-ALIF: Jurnal Penelitian Hukum Ekonomi Syariah dan Sosial Budaya Islam, Vol. 1, No. 1, Nopember 2016, page 87-97.

Mughits, Minhatul dan Ries Wulandari, "Contribution of Islamic Bank Financing for 
AM. M. Hafidz Ma'shum, Marlina: Nusantara Syariah Economy(Construction of Economic Cooperation between the Indonesian Muslim Community)

Agricultural Sector in Indonesia", Jurnal Al-Muzara'ah, Vol. 4, No.1, 2016, page 61-75.

Mukaromah, Athik, , 2011. Tinjauan Hukum Islam terhadap Sistem Persewaan Pohon Durian. tesis tidak diterbitkan, UIN Sunan Kalijaga Yogyakarta.

Nadjib, Alai, "Ekonomi Nusantara," Jurnal Tashwirul Afkar: Journal of Religion and Cultural, vol. 35, no. 1, (2016).

Nisa, Fifi Alifatun dan Hani Hanifah, “Tinjauan Ekonomi Islam terhadap Bagi Hasil Muzara'ah di Dewa Tembokrejo Muncar Banyuwangi", Economic: Jurnal Ekonomi dan Hukum Islam, Vol. 8, No. 2, 2017, page 129-144.

Nugraha, Jefri Putri, "Sistem Muzara'ah Sebagai Alternatif Pembiayaan Pertanian di Indonesia", Jurnal Iqtishodia, Vol. 1, No. 2, 2016, page 81-103.

Nurhisyam, Luqman and Mualimul Huda, "Islam Nusantara: A Middle Way?" QIJIS: Qudus International Journal of Islamic Studies, vol. 4, issue 2, (August 2016).

Doi: http:/ /dx.doi.org/10.21043/qiii s.v4i2.1763.

Nursiyamsih, Eka, "Kehidupan Sosial-Ekonomi Petani dalam Sistem Sewa Adol Oyodan pada Masyarakat Pedesaan: Kasus di Penangkan Wonotunggal Batang," thesis not published, Universitas Negeri Semarang, 2015.

Pals, Daniel S. 2012. Seven Theories of Religion. Yogyakarta: IRCiSoD

Primada, Beny Septyliyan dan Irham Zaki, “Tinjauan Mekanisme Kontrak Pengelolaan Pertanian Berbasis Adat Istiadat dalam Kajian Fiqh Muamalah: Desa Temu Kecamatan Kanor
Bojonegero" Jurnal Ekonomi Syariah dan Timur Tengah, Vol. 2, No. 11, November 2015, page 954-969.

Priyadi Unggul, dan Jannahar Saddam Ash Shidiqie, "Pelaksanaan Perjanjian Bagi Hasil Pertanian Lahan Sawah: Studi Kasus di Kec. Gamping, Kab. Sleman Yogyakarta", Jurnal Millah, Vol. 15, No. 1, Agustus 2015, 102-115.

Rafly, Muhammad dkk., "Muzaraah Lahan Pertanian menurut Kajian Hukum Islam," Jurnal Hukum Samudra Keadilan, Vol. 11, No. 2, Juli-December 2016, page 220-228.

Rasiam, "Konsep Mukhabarah dan Muzaraah di Desa Arang Limbung Kecamatan Sungai Raya Kabupaten Kubu Raya", Jurnal al-Maslahah, Vol. 12, No. 2, Oktober 2016, page 425-446.

Rohmatin, Anisatur, 2008. Tinjauan Hukum Islam terhadap Pelaksanaan Bagi Hasil Pengelolaan Lahan Tambak", skripsi thesis not published, UIN Sunan Kalijaga Yogyakarta.

Sabariah, "Sistem Pinjaman Modal Usaha Perkebunan Kelapa menurut Perspektif Ekonomi Islam: Studi Kasus Petani Kelapa Gaung Indragilir", Jurnal Hukum Islam, Vol. 14, No. 1, Nopember 2014, page 151-161.

Said, Nur, "Menggerakkan Ekonomi Maritim Syariah", Equilibrium: Jurnal Ekonomi Syariah, vol. 3, no. 2, (June 2016). doi:http:/ / dx.doi.org /10.21043/equilibrium.v3i2.126 7.

Sanjaya, Syamsul dan Lina Sudarwati, "Modal Sosial Sistem Bagi hasil dalam Beternak Sapi pada 
Masyarakat Purwosari Dolok Batu Nanggar Simalungun", Jurnal Perspektif Sosiologi, Vol. 3, No. 1, Oktober 2015, page 18-32. Sanrego, Yulizar D. dan Aam S. Rusydiana, "Peran Perbankan Syariah dalam Mendorong Agro Investasi", Jurnal Keuangan dan Perbankan, Vol. 12, No. 2, Mei 2009, page 311-324.

Saparuddin, "Praktek Bagi Hasil Aren dalam Perspektif Ekonomi Islam: Studi Kasus di Kecamatan Puncak Sorik Marapi, Mandailing Natal", thesis not published, UIN Sultan Syarif Kasim Riau, 2011.

Schiffman, Leon G., dan Leslie Lazar Kanuk. 2008. Perilaku Konsumen. Jakarta: PT. Indeks

Shobani, "Tinjauan Hukum Islam terhadap Ijarah Pohon Mangga", Jurnal Inklusif, Vol. 1, No. 1, 2016, page 13-24.

Simatupang, Pantjar dkk., "Sistem Gaduhan Sapi Tradisional Bali: Faktor Pendorong, Penopang dan Karakteristiknya", Jurnal Forum Penelitian Agro Ekonomi,Vol. 12, No.2, 1994, page 50-55,

http://dx.doi.org/10.21082/fae. v12n2.1994.50-55

Sirajuddin, Sitti Nurani dkk., "Income Analysis of Beef Cattle Breeders for Traditional Profit-Sharing System (Tesang) in South Sulawesi Province", Conference Proceeding, Vienna-Austria, 2016, page 1539-1542

Sukardi, Didi dkk., "Tinjauan Hukum Ekonomi Islam dan UUD 1945 terhadap Koperasi Perikanan Laut Mina Sumitra Indramayu", Al-Mustashfa: Jurnal Penelitian Hukum Ekonomi Islam, Vol. 2 No. 2, December 2017, page 166-180.
Swedberg, Richard. 2003. Principles of Economic Sociology. Princeton: Princeton University Press

Syahbudi, "Pemikiran dan Gerakan Sistem Ekonomi Islam di Indonesia," Hermenia, vol. 2, no.2, (2013).

Tsabita, Khontsa, "Risk Analysis of Islamic Finance in Agricultural Sector", Jurnal Al-Muzara'ah, Vol. 2, No. 2, 2014, page 88-120.

Turner, Bryan S. 2012. Relasi Agama dan Teori Sosial Kontemporer. Yogyakarta: IRCiSoD

Wahyuni, Andi Sri, "Penyesuaian Konsep Bagi Hasil AdatSyariah", Jurnal Akuntansi Multiparadigma, Vol. 4, No. 3, December 2013, page 330-507.

Wahyuningsih, Tri, "Sistem Bagi Hasil Maro sebagai Upaya Mewujudkan Solidaritas Masyarakat," Jurnal Komunitas, Vol. 3, No. 2, 2011, page 197-204.

Yulianti, Rahmani Timorita, "Ekonomi Islam dan Kearifan Lokal," Jurnal Millah, edisi khusus, (December 2010). Doi: 10.20885/millah.ed.khusus.art6.

Yunianto, Ahmad Faris. 2015. Urgensi Tradisi Gaduh Bagi Hasil Hewan Ternak dalam Kaitannya dengan Peningkatan Pendapatan Masyarakat di Dusun Jeruk Wangi Bedono Jambu Semarang. thesis not published, Universitas Negeri Semarang 